\title{
ОСНОВНЫЕ РЕЗУЛЬТАТЫ СОЗДАНИЯ НОВЫХ ФОРМ ОЗИМЫХ ТРИТИКАЛЕ
}

\author{
Лятамборг С.И., Веверииэ Е.К., Ротарь С.Г., Горе А.И. \\ Институт генетики, физиологии и защитты растений, г. Кишинёв, Молдова \\ e-mail: leatca@mail.ru
}

\begin{abstract}
The article presents the results of creation a new source material of triticale by the method of intraspecific, interspecific and intergeneric hybridization. The tying of seeds is highly dependent on the conditions of the year and the combination of crosses. As a result of the analysis signs of productivity, it was found that hybrids obtained in interspecific combinations of triticale crosses are more productive and have the effect of heterosis in relation to the parental forms. Intraspecific, interspecific, intergeneric and other improving crosses are the main means of expanding the biodiversity of triticale, creating new, more advanced varieties.
\end{abstract}

Keywords: winter triticale, hybridization, heterosis, hybrid. 


\section{Введение}

Тритикале - это новая зимостойкая зерновая культура, созданная в лабораторных условиях путем скрещивания пшеницы с рожью. После многолетних усилий, селекционерам, удалось сделать этот вид очень привлекательным для фермеров. Действительно, сегодня тритикале производит урожай, эквивалентный или даже превосходящий урожай пшеницы. Тритикале возделывается на площади более 4 млн га во всем мире, давая прибавку к мировому производству зерна свыше 15 млн тонн в год. Польша, Франция, Германия, Белоруссия, Россия и Украина, играют наиболее важную роль в качестве крупнейших европейских селекционных центров и производителей зерна тритикале.

Главной задачей селекции тритикале на современном этапе является создание высокопродуктивных сортов с высоким качеством зерна, устойчивых к биотическим и абиотическим факторам среды. Для решения проблем селекции тритикале важнейшее значение имеет наличие соответствующего исходного материала. Следовательно, селекционный процесс начинается с изучения и оценки исходного материала [4]. Тритикале наряду с высоким потенциалом продуктивности обладает повышенной устойчивостью к экологическим стрессам и болезням и является перспективной культурой для расширения сырьевой базы хлебопекарной промышленности $[1,6,7]$.

В Республике Молдова тритикале выращивается как зерновая культура с 1980-х годов. Активной разработкой селекционно-генетических моделей по получению исходного материала и созданию новых сортов тритикале занимались: Буюкли П.И., Котельникова Л.К., Веверицэ Е.К. [3]. В данной работе отражены результаты создания нового исходного материала тритикале методом внутривидовой, межвидовой и межродовой гибридизации и представлены результаты анализа величины гетерозиса гибридов F1 с целью выделения комбинаций с наибольшим числом хозяйственно ценных признаков.

\section{Материал и методы}

Исследования проводились на экспериментальном поле Института Генетики, Физиологии и Защиты Растений. В качестве исходного материала для гибридизации нами использовались генотипы и сорта тритикале, пшеницы и ржи различного генетического и географического происхождения (Румыния, Болгария, Украина, Россия, Беларусь, Польша и др.), а также формы и сорта нашей селекции, которые соответствовали реализации поставленной цели. Питомники (гибридизации, гибридный и селекционный) высевали однорядковыми делянками длиной $1,5 \mathrm{~m}$ x $0,40 \mathrm{M}$. Полученные гибриды анализировали по высоте растения, продуктивной кустистости, длине, числу колосков и зерен, массе зерна главного колоса, массе 1000 зерен. Для количественной оценки гетерозиса использовали 2 метода: способность гибридов F1 превосходить по данному признаку лучшую из родительских форм (Гист) и способность гибридов $\mathrm{F}_{1}$ превосходить по данному признаку средние показатели данного признака у родительских форм (Ггип) [5]. Закладку опытов, фенологические наблюдения, полевые учеты и структурный анализ проводили согласно методике полевого опыта Б.А.Доспехова [2].

\section{Результаты и обсуждения}

В наших исследованиях отражены вопросы создания нового исходного материала тритикале с использованием различных методов гибридизации. Основываясь на изучении исходного материала были отобраны наиболее ценные из них в качестве генетических источников при создании сортов, обладающих повышенной 
адаптивностью, повышенным потенциалом урожайности зерна. В период 2016-2019 годов проведено 260 комбинации скрещиваний. Было кастрировано и опылено 33516 цветков и получено 7873 гибридных зерен. Результаты скрещиваний представлены в таблице 1. Как видно из таблицы завязываемость семян зависит от комбинации скрещиваний, условий года и совместимости родительских форм. Завязываемость гибридных зерен имеет большой диапазон варьирования, и для внутривидовой гибридизации она составила от 6,3 до $79,9 \%$, межвидовой - от 2,2 до $68,7 \%$ и межродовой от $0-14,7 \%$.

Таблица 1. Завязываемость гибридных зерен в зависимости от вида скрещиваний 2016-2019 гг

\begin{tabular}{|c|c|c|c|c|c|}
\hline $\begin{array}{c}\text { Комбинации } \\
\text { скрещиваний }+\underset{ }{\jmath}\end{array}$ & $\begin{array}{c}\text { Число } \\
\text { комбинаций }\end{array}$ & $\begin{array}{c}\text { Кол-во } \\
\text { цветков }\end{array}$ & $\begin{array}{c}\text { Гибридных } \\
\text { зерен }\end{array}$ & $\begin{array}{c}\text { Завязываемость, } \\
\%\end{array}$ & $\begin{array}{c}\text { Вариация } \\
\text { мин- } \\
\text { макс, \% }\end{array}$ \\
\hline \multicolumn{6}{|l|}{ Внутривидовая } \\
\hline Tr-le x tr-le $(42 \times 42)$ & 68 & 8818 & 4041 & 45,9 & $6,3-79,9$ \\
\hline \multicolumn{6}{|l|}{ Межвидовая } \\
\hline $\begin{array}{l}\text { Tr-le x tr- } \\
\text { le }(42 \times 56)(56 \times 42)\end{array}$ & 25 & 3279 & 1213 & 37,4 & $\begin{array}{c}13,5- \\
68,7 \\
\end{array}$ \\
\hline Tr-le x Tr.aestivum & 43 & 5662 & 701 & 12,3 & $2,2-40,6$ \\
\hline Tr.aestivum x Tr-le & 43 & 5386 & 1478 & 32,2 & $2,3-62,1$ \\
\hline \multicolumn{6}{|l|}{ Межродовая } \\
\hline Tr.aest. x S.cereale & 81 & 10371 & 440 & 6,7 & $0-14,7$ \\
\hline Всего & 260 & 33516 & 7873 & & \\
\hline
\end{tabular}

Из этих экспериментальных данных можно сделать вывод, что при внутривидовой гибридизации завязываемость семян составляет 45,9\%. В межвидовых гибридизациях с участием различных сортов пшеницы и тритикале мы наблюдаем большое различие в завязываемости гибридных зерен. Комбинации между гексаплоидными тритикале $(2 \mathrm{n}=42)$ и октоплоидными тритикале $(2 \mathrm{n}=56)$ показывают завязываемость зерен $37,4 \%$, а тритикале $(2 n=42)$ с мягкой пшеницей $(2 n=42)$ и обратные, завязываемость зерен более разнообразна от 12,3 до 32,2\%. В межродовых гибридах завязываемость семян составила $6,7 \%$. В зависимости от типа скрещивания и индивидуальных особенностей родительских пар завязываемость гибридных семян варьировала от 0 до 79,9\%. Зерна у отдаленных гибридов отличались от внутривидовых большой деформированностью, щуплостью и пониженной всхожестью. Таким образом, за эти годы был создан новый, богатый исходный материал для использования в селекции тритикале.

В межвидовых скрещиваниях по многим признакам нередко проявлялся гетерозис. Полученные гибриды $\mathrm{F}_{1}$ анализировали по структуре продуктивности главного колоса (длина колоса, количество колосков, количество зерен, масса зерен и масса 1000 зерен). В большинстве гибридных комбинаций наблюдался гетерозисный эффект. Данные приведены в таблице 2 и рис. 1. 
Таблица 2. Гетерозис (\%) у внутривидовых гибридов $F_{1}$ озимой тритикале, 2019 г

\begin{tabular}{|c|c|c|c|c|c|c|c|c|c|c|}
\hline \multirow{2}{*}{$\begin{array}{l}\text { Гибридны } \\
\mathrm{e} \\
\text { комбинац } \\
\text { ии }\end{array}$} & \multicolumn{2}{|c|}{ Дл.колоса } & \multicolumn{2}{|c|}{ Кол.кол-ков } & \multicolumn{2}{|c|}{ Кол.зерен } & \multicolumn{2}{|c|}{ М.зерен } & \multicolumn{2}{|c|}{ М.1000зерен } \\
\hline & $\begin{array}{l}\text { Гист, } \\
\%\end{array}$ & $\begin{array}{l}\text { Ггип, } \\
\%\end{array}$ & $\begin{array}{l}\text { Гист, } \\
\%\end{array}$ & $\begin{array}{l}\text { Ггип, } \\
\%\end{array}$ & $\begin{array}{l}\text { Гист, } \\
\%\end{array}$ & $\begin{array}{l}\text { Ггип, } \\
\%\end{array}$ & $\begin{array}{l}\text { Гист, } \\
\%\end{array}$ & $\begin{array}{l}\text { Ггип, } \\
\%\end{array}$ & $\begin{array}{l}\text { Гист, } \\
\%\end{array}$ & $\begin{array}{l}\text { Ггип, } \\
\%\end{array}$ \\
\hline $\begin{array}{l}\text { Трил х } \\
\text { ЛТ76872 }\end{array}$ & 4,41 & 7,40 & 2,42 & 6,09 & $-20,74$ & $-18,52$ & $-23,91$ & $-12,50$ & $-10,17$ & 5,18 \\
\hline $\begin{array}{l}\text { л.Ир.Болг } \\
\text {. х } \\
\text { ЛТ76872 }\end{array}$ & 17,47 & 19,18 & 4,51 & 10,69 & $-14,34$ & $-5,01$ & 3,39 & 9,96 & $-2,63$ & 13,04 \\
\hline $\begin{array}{l}\text { Канар x } \\
\text { Стил } \\
\end{array}$ & 2,47 & 15,92 & 7,62 & 10,45 & 2,88 & 7,67 & 10,28 & 11,67 & 10,60 & 14,62 \\
\hline $\begin{array}{l}\text { Букет x } \\
\text { Шаланда }\end{array}$ & 4,25 & 5,64 & 4,85 & 7,8 & $-3,58$ & 3,02 & $-11,48$ & 0,69 & $-8,64$ & $-2,04$ \\
\hline $\begin{array}{l}\text { ЛТ76872 } \\
\text { х Стил } \\
\end{array}$ & 3,96 & 10,48 & 2,23 & 5,16 & $-8,89$ & $-5,87$ & $-3,06$ & 9,78 & $-0,43$ & 15,57 \\
\hline $\begin{array}{l}\text { Лин.12 x } \\
\text { Амол }\end{array}$ & $-1,55$ & $-10,73$ & $-5,71$ & $-2,61$ & $-6,01$ & $-1,38$ & 9,06 & 18,33 & 15,86 & 20,91 \\
\hline $\begin{array}{l}161 / 88- \\
233 \text { x } \\
\text { Амол }\end{array}$ & 0,33 & 7,50 & 2,52 & 7,50 & $-24,86$ & $-14,90$ & $-21,99$ & $-3,74$ & 2,43 & 14,23 \\
\hline $\begin{array}{l}\text { Канар х } \\
\text { Инген } 40\end{array}$ & 12,58 & 30,11 & 7,94 & 17,61 & $-18,47$ & $-1,46$ & $-1,12$ & 23,98 & 21,28 & 27,70 \\
\hline $\begin{array}{l}\text { АД } 1467 \text { x } \\
\text { Кастор }\end{array}$ & 6,77 & 9,82 & 5,00 & 2,91 & $-15,98$ & $-9,99$ & $-16,97$ & $-11,28$ & $-14,06$ & $-2,48$ \\
\hline $\begin{array}{l}\text { Розовское } \\
\text { х 95W73- } \\
2-1 \\
\end{array}$ & $-3,58$ & 12,04 & 6,62 & 9,12 & $-17,97$ & $-8,72$ & $-3,52$ & 3,63 & 10,08 & 13,89 \\
\hline $\begin{array}{l}\text { 95W73-2- } \\
1 \text { х Канар }\end{array}$ & $-2,22$ & 11,25 & 2,71 & 4,67 & $-22,44$ & $-15,05$ & $-4,05$ & $-0,65$ & 23,10 & 16,50 \\
\hline $\begin{array}{l}161 / 88- \\
233 \text { х АД } \\
1467\end{array}$ & $-1,36$ & 3,33 & 8,10 & 8,55 & $-10,34$ & $-10,52$ & $-17,34$ & $-7,03$ & $-7,43$ & 3,36 \\
\hline $\begin{array}{l}\text { л.Ир.Болг } \\
\text { x Гайдук } \\
\end{array}$ & 10,23 & 19,13 & 3,35 & 8,68 & 10,51 & 13,19 & 22,89 & 24,23 & 5,38 & 9,37 \\
\hline
\end{tabular}

лин.Ир.Болгария х Гайдук

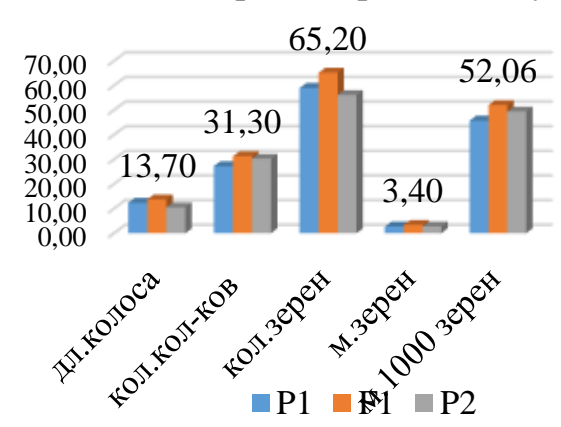

Канар х Стил

77,60
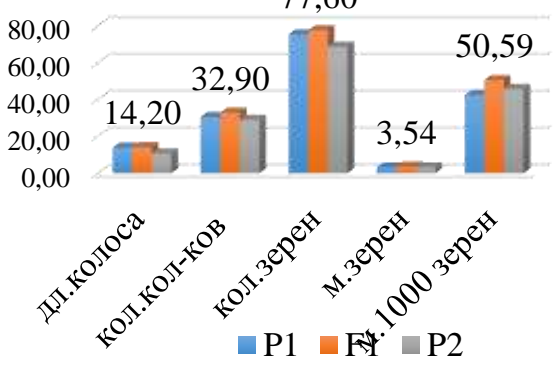

Рис.1 Родительские формы и $F_{1}$ у внутривидовых гибридов тритикале 
Исследования показали, что уровень гетерозиса по отношению к лучшему родителю составил в данных комбинациях 2,47-17,47\% по длине колоса, по количеству колосков - 2,23-8,1\%, по количеству зерен с колоса - 2,88-10,53\%, по массе зерен 3,39-22,89\%, по массе 1000 семян - 2,43-23,10\%. Уровень гетерозиса по отношению к среднему значению признака у родителей составил 3,33-30,11\% по длине колоса, по количеству колосков - 2,91-17,61\%, по количеству зерен - 3,02-13,19\%, по массе зерен 0,69-24,23\%, по массе 1000 семян - 3,36-27,70\%. Эффект гетерозиса варьировал в зависимости от комбинации скрещивания. При анализе гибридов были выделены две комбинации лин. Ир. Болгария х Гайдук и Канар х Стил, которые обладали положительным истинным и гипотетическим гетерозисом по всем показателям продуктивности колоса. Данные гибридные формы могут служить ценным селекционным материалом при создании новых сортов тритикале.

У межродовых гибридов гетерозис в первых поколениях не выражен, гибриды проявили существенное снижение озерненности колоса по сравнению с родительскими формами, что обусловлено нарушениями мейоза и является закономерным для отдаленных гибридов. В последующих поколениях проводили отборы, изучая линии в гибридном питомнике $\mathrm{F}_{2}-\mathrm{F}_{4}$, селекционном, контрольном и сортоиспытании. Лучшие из них превышали по урожайности стандартные сорта тритикале и пшеницы, обладали высокой устойчивостью к пониженным температурам, к весеннее - летней засухе и болезням.

\section{Выводы}

Таким образом, в результате внутривидовой, межвидовой и межродовой гибридизации создан новый исходный материал для селекции тритикале. Проведенные исследования позволили нам выделить ряд ценных комбинаций скрещивания, которые в гибридном потомстве могут формировать генотипы с комплексом хозяйственноценных признаков и свойств.

По результатам проведенного анализа установлено, что у большинства изученных гибридов $F_{1}$ гетерозис проявлялся одновременно по двум-трем признакам, a две гибридные комбинации лин.Ир.Болгария х Гайдук и Канар х Стил превосходили свои родительские формы по всем пяти признакам (длина колоса, количество колосков, количество зерен, масса зерен и масса 1000 зерен). Данные гибридные формы могут служить ценным селекционным материалом при создании новых сортов озимого тритикале.

\section{Библиография}

1. Горянина Т. Возделывание тритикале в условиях Самарской области: научнопрактические рекомендации. Самара: ФГБНУ «Самарский НИИСХ» 2016, 31 с.

2. Доспехов Б.А. Методика полевого опыта. М.:Агропромиздат, $1985.351 \mathrm{c.}$

3. Котелникова Л., Буюкли П., Веверицэ Е. Создание нового исходного материала в селекции тритикале. В: Генетика и селекция тритикале в Молдове, Кишинёв, Штиинца, 1992 , c. 5-23.

4. Медведев А.М. Озимая и яровая тритикале в Российской федерации/Коллективная монография. Немчиновка- Москва, МосНИИСХ, 2017, 284 с.

5. Омаров Д.С. К методике учета и оценка гетерозиса у растений. С-х. биология, 1975, Т.X., №1, с. 123-127.

6. Орлова Н.С., Каневская И.Ю. Характеристика линий озимой тритикале, полученных от внутривидовых скрещиваний по ряду хозяйственно значимым показателям. В: 
Интродукция нетрадиционных и редких растений: матер. 9-ой междунар. науч.методич. конф., 21-25 июня, Мичуринск, 2010, с.121-124.

7. Рубец В.С., Игонин В.Н., Пыльнев В.В. Селекция озимой тритикале в РГАУ-МСХА имени К.А. Тимирязева: история, особенности, достижения. В: Известия ТСХА, М.: Изд-во РГАУ-МСХА им. К.А. Тимирязева, 2014, Вып. 1, с. 115-124. 